\title{
Wiceprezes Rady Ministrów w polskiej regulacji konstytucyjnej i praktyce politycznej
}

\author{
Konrad Sktadowski \\ Uniwersytet Łódzki, Wydział Prawa i Administracji \\ Katedra Prawa Konstytucyjnego
}

Skład Rady Ministrów został określony w art. 147 Konstytucji RP z 2 kwietnia 1997 r. Brzmienie przepisu jest następujące:

1. Rada Ministrów składa się z Prezesa Rady Ministrów i ministrów.

2. W skład Rady Ministrów mogą być powoływani wiceprezesi Rady Ministrów.

3. Prezes i wiceprezes Rady Ministrów mogą pełnić także funkcję ministra.

4. W skład Rady Ministrów mogą być ponadto powoływani przewodniczący określonych w ustawach komitetów.

Na tej podstawie w polskiej literaturze przedmiotu często wskazuje się, że Rada Ministrów posiada skład obligatoryjny i fakultatywny ${ }^{1}$. Niektórzy autorzy dokonują jednak wyróżnienia trzech wariantów składu Rady Ministrów: minimalny, rozszerzony i maksymalny ${ }^{2}$. Skład obligatoryjny stanowią Prezes Rady Ministrów i ministrowie. Liczba ministrów uzależniona jest, w sensie prawnym, od trzech czynników: przepisów konstytucji, postanowień ustawy o działach administracji rządowej oraz rozporządzenia Prezesa Rady Ministrów wydanego na podstawie art. 33 ustawy o Radzie Ministrów ${ }^{3}$. Konstytucja w art. 133 ust. 3, art. 134 ust. 2, art. 187 ust. 1 przesądza o powołaniu trzech tzw. ministrów konstytucyjnych. Są to: minister właściwy w zakresie spraw zagranicznych, minister obrony narodowej oraz minister sprawiedliwości. Ustawa o działach administracji rządowej wskazuje zakres przedmiotowy działania właściwych ministrów. Natomiast rozporządzenie

1 W. Brodziński, Rada Ministrów, [w:] D. Górecki (red.), Polskie prawo konstytucyjne, wyd. V, Warszawa 2015, s. 199; R. Mojak, Władza wykonawcza - Rada Ministrów i administracja rzq̨owa, [w:] E. Gdulewicz (red.), Konstytucyjny system organów państwowych, Lublin 2009, s. 194.

2 M. Grzybowski, Pozycja ustrojowa Wiceprezesa Rady Ministrów, [w:] P. Tuleja, M. Florczak-Wątor, S. Kubasa (red.), Prawa człowieka, społeczeństwo obywatelskie, państwo demokratyczne. Księga jubileuszowa dedykowana Profesorowi Pawłowi Sarneckiemu, Warszawa 2010, s. 285.

3 Ustawa o działach administracji rządowej, Dz.U. z 1997 r., nr 141, poz. 943 ze zm.; ustawa o Radzie Ministrów, Dz.U. z 1996 r., nr 106, poz. 492 ze zm. 
Prezesa Rady Ministrów stanowi powierzenie konkretnemu ministrowi określonego działu administracji i poprzez to ustala szczegółowy zakres działania ministra. Rozporządzenie to wydawane jest bezpośrednio po powołaniu Rady Ministrów lub - gdy minister został powołany w innym czasie - niezwłocznie po jego powołaniu (art. 33 ust. 1 pkt 2). Tym samym rozporządzenie Prezesa Rady Ministrów przesądza o liczbie ministrów w rządzie oraz ich zakresie przedmiotowym działania. Do premiera należy jednocześnie decyzja, czy w składzie Rady Ministrów znajdą się oprócz ministrów resortowych również tzw. ministrowie bez teki, którzy wypełniają zadania powierzony im przez premiera, a określone $\mathrm{w}$ drodze wydanego przez niego rozporządzenia.

Natomiast w składzie fakultatywnym rządu mogą znaleźć się nadto wiceprezes lub wiceprezesi Rady Ministrów oraz przewodniczący określonych w ustawach komitetów.

Decydujący wpływ na utworzenie rządu i nadanie mu określonych ram organizacyjnych posiada niewątpliwie Prezes Rady Ministrów. Dotyczy to przede wszystkim prawa premiera do wyodrębnienia w składzie rządu stanowiska wiceprezesa lub wiceprezesów Rady Ministrów. Wprawdzie w literaturze przedmiotu podnosi się, że prezydent jest też „organem centralnym współdecydującym o wykreowaniu stanowiska wiceprezesa Rady Ministrów”", ja jednak nie podzielam tego poglądu. Sądzę, że treść norm konstytucyjnych dotyczących udziału prezydenta w powoływaniu Rady Ministrów nie daje podstaw do kwestionowania przez głowę państwa prawa premiera do kształtowania składu rządu zarówno pod względem personalnym, jak i instytucjonalnym (utworzenia określonych stanowisk). Podzielam pogląd wyrażony przez S. Patyrę, że premier dysponuje formalnie pełną swobodą w odniesieniu do stanowisk wicepremierów: „Premier decyduje o liczbie wicepremierów w rządzie, jak również o tym, czy mają oni łączyć tę funkcję ze

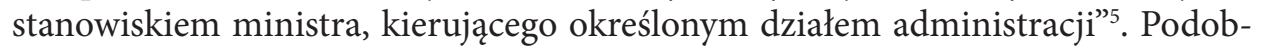
ne stanowisko zajmuje M. Bożek: „Funkcjonowanie w składzie Rady Ministrów wicepremiera zależy od decyzji premiera, który kieruje $\mathrm{w}$ tej sprawie stosowny wniosek do Prezydenta Rzeczypospolitej, zazwyczaj jeszcze na etapie formowania gabinetu rządowego" ${ }^{\circ}$.

Ustawa o działach administracji rządowej określa w sensie normatywnym skład rządu i w ten sposób legislatywa uzyskuje wpływ na kształt organizacyjny Rady Ministrów. Jednak pozostawia premierowi „pewien zakres swobody w inspirowaniu określonego składu liczbowego, struktury i podziału przedmiotowego zadań

4 M. Grzybowski, Pozycja ustrojowa..., s. 287-288.

5 S. Patyra, Prawnoustrojowy status Prezesa Rady Ministrów w świetle Konstytucji z 2 kwietnia 1997 r., Warszawa 2002, s. 75.

6 M. Bożek, Zapewnienie ciągłości w kierowaniu pracami Rady Ministrów pod rządami Konstytucji RP, „Przegląd Sejmowy” 2010, nr 6, s. 15. 
w obrębie Rady Ministrów”7. Jednocześnie należy podkreślić, że premier stojący na czele większości parlamentarnej posiada przemożny wpływ na treść ustaw uchwalanych przez parlament i tym samym może doprowadzić do nowelizacji ustawy zgodnej z jego oczekiwaniami.

Oczywiście, poza czynnikami formalnoprawnymi w grę wchodzą także okoliczności pozaprawne, które mogą wpływać na kształt Rady Ministrów. W ich ramach faktyczny wpływ prezydenta na organizacyjny i personalny skład rządu może być znaczny. Jednak będzie to miało miejsce w przypadku zbiegu co najmniej dwóch okoliczności. Pierwsza to brak większości parlamentarnej, a druga - determinacja kandydata na premiera do utworzenia rządu i związana z tym skłonność do ustępstw na rzecz prezydenta. Jeżeli w trakcie formowania rządu, w konstytucyjnie określonej procedurze, kandydat na premiera dysponuje poparciem większości parlamentarnej, to oddziaływanie prezydenta na kształt rządu nie ma miejsca. Samodzielność premiera w podejmowaniu decyzji w sprawie utworzenia stanowiska wicepremiera jest słusznie uznawana w literaturze za okoliczność wzmacniającą pozycję premiera ${ }^{8}$. Decyzja o powołaniu wiceprezesa Rady Ministrów może być inspirowana rozmaitymi przyczynami, lecz wszystkie one posiadają charakter przesłanek z gruntu politycznych.

Regulacja prawna dotycząca wiceprezesa Rady Ministrów jest w Polsce wyjątkowo oględna. Oprócz przywołanego przepisu Konstytucji RP jedynie w art. 6 ustawy z dnia 8 sierpnia 1996 r. o Radzie Ministrów znajduje się krótka wzmianka na temat wicepremiera, związana z problematyką zastępstwa Prezesa Rady Ministrów przez wiceprezesa:

Art. 6

1. W razie nieobecności Prezesa Rady Ministrów lub w innym wypadku czasowej niemożności wykonywania przez niego obowiązków w Radzie Ministrów, pracami Rady Ministrów kieruje wiceprezes Rady Ministrów wyznaczony przez Prezesa Rady Ministrów lub jeden z ministrów, jeżeli wiceprezes Rady Ministrów nie został powołany.

2. Wiceprezes Rady Ministrów wykonuje, w imieniu Prezesa Rady Ministrów, zadania i kompetencje w zakresie powierzonym przez Prezesa Rady Ministrów.

W literaturze wskazuje się, że z samej nazwy „wiceprezes” wynika, iż jest lub są oni zastępcami premiera ${ }^{9}$, jednak ani przepisy konstytucji, ani ustaw nie pozwalają na wskazanie instrumentów czy procedur związanych z wykonywaniem tego zastępstwa. Przyjęcie interpretacji, że wiceprezes Rady Ministrów może być z urzędu zastępcą premiera jest, moim zdaniem, trudne do obrony ${ }^{10}$. Stanowisko takie mo-

7 M. Grzybowski, Konstytucyjne i ustawowe uwarunkowania struktury rzqdu a praktyka ustrojowa, [w:] M. Grzybowski (red.), System rządów Rzeczypospolitej Polskiej. Założenia konstytucyjne a praktyka ustrojowa, Warszawa 2006, s. 120.

8 S. Patyra, Prawnoustrojowy status..., s. 75.

9 P. Sarnecki, Uwaga do art. 147, [w:] L. Garlicki (red.) Konstytucja Rzeczypospolitej Polskiej. Komentarz, t. II, Warszawa 2001, s. 3.

10 W. Skrzydło, Konstytucja Rzeczypospolitej Polskiej. Komentarz, Kraków 2002, s. 156. 
głoby być uzasadnione w sytuacji, gdy w składzie Rady Ministrów jest tylko jeden wiceprezes, ale i w tym przypadku nie sposób mówić o zastępstwie z mocy prawa, gdyż do tego za każdym razem potrzebne jest upoważnienie ze strony premiera. Podzielam argumentację M. Bożka wymieniającego powody, dla których nie można przyjąć koncepcji zastępstwa premiera z mocy prawa przez wiceprezesa Rady Ministrów:

wiceprezes Rady Ministrów nie ma swoich „samodzielnych” kompetencji, a realizuje jedynie określone kompetencje premiera, z wyjątkiem sytuacji, kiedy jednocześnie pełni funkcję ministra, ale to nie zmienia jego formalnego statusu jako wiceprezesa Rady Ministrów. Co za tym idzie, to premier „powierza” wicepremierowi pewien zakres „zadań i kompetencji", które ten wykonuje nie we własnym imieniu, lecz prezesa Rady Ministrów. [...] Kluczowym elementem tej konstrukcji [...] jest akt scedowania pewnych kompetencji przez premiera na osobę wicepremiera. Jest to warunek niezbędny, bez którego wiceprezes Rady Ministrów nie może działać. Formalnie rzecz ujmując, akt powołania danej osoby do składu rządu na stanowisko wicepremiera nie stanowi wystarczającej podstawy do zajmowania się przez powołanego sprawami pozostającymi w gestii Rady Ministrów ${ }^{11}$.

Reasumując kwestię zastępstwa premiera, należy wskazać na charakterystyczne cechy tej instytucji wynikające $\mathrm{z}$ rozwiązania przyjętego w ustawie: 1) premiera mogą zastępować zarówno wiceprezes Rady Ministrów, jak i jeden z ministrów, jeżeli w składzie rządu nie funkcjonuje wicepremier; 2) wiceprezes zastępujący premiera nie działa w imieniu własnym, lecz podejmuje działania w imieniu Prezesa Rady Ministrów; 3) wykonywanie obowiązków premiera wymaga wyznaczenia przez niego określonej osoby do kierowania pracami Rady Ministrów; 4) upoważnienie do zastępowania premiera ma zawsze charakter czasowy; 5) do zastępowania premiera może on za każdym razem uprawniać innego członka Rady Ministrów, niekoniecznie wiceprezesa; 6) w kompetencjach Prezesa Rady Ministrów nie znajduje się uprawnienie do wyznaczenia jednego $\mathrm{z}$ wiceprezesów Rady Ministrów jako stałego zastępcy. Na podstawie obowiązującej regulacji normatywnej nie wykształciła się dotąd trwała praktyka związana z zastępstwem Prezesa Rady Ministrów.

W świetle obowiązujących przepisów trudno nadawać szczególną rolę wiceprezesowi Rady Ministrów, nic nie wskazuje także na jakąś wyjątkową w stosunku do ministrów i innych członków Rady Ministrów pozycję ustrojowo-prawną. Szczególna rola wicepremierów nie została określona ani w konstytucji, ani w ustawach, również w Regulaminie pracy Rady Ministrów ${ }^{12}$; w żadnym przepisie nie podkreślono szczególnej roli wiceprezesa Rady Ministrów. Znamienne jest, że w Dziale II uchwały, zatytułowanym „Rada Ministrów”, w żadnym paragrafie nie pada nawet nazwa „wiceprezes Rady Ministrów”, a uchwała posługuje się wyłącznie określeniem „członkowie Rady Ministrów”.

11 M. Bożek, Zapewnienie ciągłości w kierowaniu..., s. 14.

12 Uchwała nr 190 Rady Ministrów z 29 października 2013 r. - Regulamin pracy Rady Ministrów, tekst jedn. M.P. z 2016 r., poz. 1006. 
W ramach polskiej regulacji nie ma podstaw do wskazania pierwszego zastępcy Prezesa Rady Ministrów. Nie ma również, znanej w innych systemach, instytucji jakichś węższych gremiów w ramach rządu, których członkami byliby premier i wicepremierzy ${ }^{13}$. To w praktyce może rodzić problemy związane z ciągłością działania Rady Ministrów w razie nagłej nieobecności premiera ${ }^{14}$. W związku z tym, że wicepremierzy są w Polsce najczęściej także ministrami, ich zakres kompetencji związany jest z zakresem przedmiotowym działania ministerstwa, na czele którego stoją i tym samym wynika to z ustawy o działach administracji rządowej z 4 września 1997 r. Tradycja równoległego pełnienia funkcji wicepremiera i ministra "resortowego” jest w Polsce ugruntowana ${ }^{15}$. Mimo że wiceprezes Rady Ministrów pozbawiony jest jakiegoś szczególnego znaczenia wynikającego z przepisów prawa, to praktyka powoływania wiceprezesów w kolejnych składach rządów jest powszechna. Od momentu wejścia w życie obowiązującej konstytucji wicepremierzy wchodzili w skład każdego kolejnego rządu. Przed uchwaleniem konstytucji również miał miejsce ten stan rzeczy. Wicepremierów nie było jedynie w rządzie premiera Jana Olszewskiego, urzędującego od grudnia 1991 r. do lipca 1992 r.

Analiza praktyki politycznej z okresu obowiązywania Konstytucji z 1997 r. pozwala na wyciągnięcie pewnych wniosków, pozwalających na dokonanie oceny statusu ustrojowego i politycznego wiceprezesa Rady Ministrów. Dotychczasowa praktyka potwierdza tezę, że wicepremier pełni jednocześnie stanowisko jakiegoś ministra resortowego. W gronie ponad dwudziestu wicepremierów, jacy do tej pory wchodzili w skład kolejnych rządów, tylko troje nie było ministrami kierującymi działem administracji. Pierwszy taki przypadek miał miejsce od 11 czerwca do 24 listopada 2004 r. w rządzie Marka Belki. Izabela Jaruga-Nowacka była wicepremierem i ministrem-członkiem Rady Ministrów. Podobna sytuacja miała miejsce od 8 maja do 16 listopada 2007 r., gdy na stanowisko wicepremiera został powołany przez premiera Jarosława Kaczyńskiego minister bez teki, przewodniczący Komitetu Stałego Rady Ministrów Przemysław Gosiewski. Trzeci ma miejsce obecnie - od 11 grudnia 2017 r. W rządzie Mateusza Morawieckiego funkcję wicepremiera pełni Beata Szydło, która nie jest ministrem. Jednocześnie premier Mateusz Morawiecki nie wydał zarządzenia, które określałoby jej zakres obowiązków jako wiceprezesa. Jedynie na podstawie zarządzenia Prezesa Rady Ministrów można stwierdzić, że wicepremier Beata Szydło wchodzi w skład Komitetu Społecznego Rady Ministrów, któremu przewodniczy. Po raz pierwszy w skład Rady

13 Takie rozwiązanie znane jest np. w Chorwacji. Regulacja chorwacka pozwala na powołanie pierwszego wicepremiera. Jednocześnie istnieje w tym systemie węższy gabinet, złożony z premiera i wicepremierów. Patrz: K. Składowski, System rzq̨ów w Republice Chorwacji, Łódź 2013, s. 311, 317-318.

14 Zwraca na to uwagę M. Bożek, Zapewnienie ciągłości w kierowaniu..., s. 15-17.

15 M. Grzybowski, Konstytucyjne i ustawowe uwarunkowania..., s. 124. 
Ministrów wchodzi wicepremier, który nie pełni równocześnie żadnej funkcji ministerialnej, a jednocześnie posiada niesprecyzowany zakres obowiązków.

Liczba wicepremierów w kolejnych Radach Ministrów nigdy nie była większa niż trzech, ale jednocześnie nie mniejsza niż dwóch. W aktualnym rządzie premiera Mateusza Morawieckiego (PiS) jest troje wicepremierów. Piotr Gliński - minister kultury i dziedzictwa narodowego, Jarosław Gowin - minister szkolnictwa wyższego i Beata Szydło, która nie pełni żadnej funkcji ministerialnej.

W rządzie Beaty Szydło (PiS) było trzech wicepremierów: Mateusz Morawiecki, który piastował też funkcję ministra rozwoju i finansów, Piotr Gliński i Jarosław Gowin, którzy piastowali te same stanowiska ministerialne, jakie zajmują obecnie w rządzie Mateusza Morawieckiego.

W rządzie Ewy Kopacz (koalicja PO-PSL) funkcję wicepremiera pełnił Janusz Piechociński (PSL), który był także ministrem gospodarki oraz Tomasz Siemoniak (PO) będący ministrem obrony narodowej. Dwaj wicepremierzy reprezentowali dwie partie będące członkami koalicji rządzącej.

W drugim rządzie Donalda Tuska (koalicja PO-PSL) funkcję wicepremierów piastowali Waldemar Pawlak (PSL) - minister gospodarki, Elżbieta Bieńkowska (PO) - minister rozwoju regionalnego oraz minister infrastruktury i rozwoju, a także Jan Vincent-Rostowski (PO) - minister finansów. Zmiany kierownictwa $\mathrm{w}$ partii, jakie zaszły w łonie jednego z koalicjantów, doprowadziły do zmian w składzie Rady Ministrów. Stąd na stanowisku wicepremiera i ministra gospodarki Waldemara Pawlaka zastąpił Janusz Piechociński.

Pierwszy rząd Donalda Tuska (koalicja PO-PSL) posiadał dwóch wicepremierów, którzy reprezentowali dwie partie tworzące koalicję rządzącą. Byli to: Waldemar Pawlak (PSL) - wicepremier i minister gospodarki oraz Grzegorz Schetyna (PO) - wicepremier i minister spraw wewnętrznych i administracji.

Rząd Jarosława Kaczyńskiego (PIS, początkowo rząd koalicyjny PiS-LPR-Samoobrona) miał początkowo trzech wicepremierów. Było to odzwierciedleniem składu koalicji rządzącej. Byli to: Ludwik Dorn (PiS) - wicepremier i minister spraw wewnętrznych i administracji, Roman Giertych (LPR) - wicepremier i minister edukacji narodowej, Andrzej Lepper (Samoobrona) wicepremier i minister rolnictwa i rozwoju wsi. W późniejszym czasie na skutek zawirowań politycznych związanych z rekonstrukcjami rządu oraz rozpadem koalicji wicepremierami zostali: Przemysław Gosiewski (PiS) - wicepremier i minister-członek Rady Ministrów, Zyta Gilowska (PiS) - wicepremier i minister finansów.

W rządzie Kazimierza Marcinkiewicza w chwili jego zaprzysiężenia nie było wicepremierów. Było to spowodowane przede wszystkim trwaniem negocjacji między partiami parlamentarnymi na temat stworzenia trwałej większości rządzącej. Po miesiącu od zaprzysiężenia rządu, 21 listopada 2005 r. na stanowisko wicepremiera został powołany Ludwik Dorn (PiS) - minister spraw wewnętrznych i administracji, a 7 stycznia 2006 r. na stanowisko wicepremiera i ministra finansów została mianowana Zyta Gilowska. W maju 2006 r. w związku z podpisaniem 
umowy koalicyjnej w skład rządu powołani zostali przedstawiciele partii koalicyjnych, w tym: Roman Giertych (LPR) - wicepremier i minister edukacji narodowej i Andrzej Lepper (Samoobrona) - wicepremier i minister rolnictwa i rozwoju wsi.

Rząd Marka Belki funkcjonował w dwóch odsłonach. Po raz pierwszy Marek Belka został powołany na stanowisko Prezesa Rady Ministrów 2 maja 2004 r. Jednak premier nie uzyskał wotum zaufania od Sejmu i podał się do dymisji. W związku z tym, że próba powołania rządu pod przywództwem innego polityka się nie powiodła, Prezydent misję tworzenia rządu powierzył ponownie Markowi Belce. W tzw. procedurze rezerwowej rząd Marka Belki 15 października 2004 r. otrzymał wotum zaufania od Sejmu. W obu gabinetach funkcje wicepremierów pełnili ci sami politycy: Jerzy Hausner (SLD) - wicepremier i minister gospodarki i pracy oraz Izabela Jaruga-Nowacka (Unia Lewicy RP) - wicepremier i minister polityki społecznej, do 24 listopada 2004 r. była wicepremierem i ministrem-członkiem Rady Ministrów.

W rządzie Leszka Millera (koalicja SLD-PSL-UP) zachodziły zmiany na stanowiskach wicepremierów ze względu na rozpad koalicji rządzącej. Początkowo w rządzie znajdowało się trzech wicepremierów: Marek Belka (SLD) - wicepremier i minister finansów, Jarosław Kalinowski (PSL) - wicepremier, minister rolnictwa i rozwoju wsi, Marek Pol (UP) - wicepremier i minister infrastruktury. $\mathrm{Na}$ skutek rozpadu koalicji oraz rekonstrukcji rządu funkcję wicepremiera objął Jerzy Hausner (SLD), dotychczasowy minister pracy i polityki społecznej, a w późniejszym czasie minister gospodarki, pracy i polityki społecznej. Po ustąpieniu z zajmowanych stanowisk rządowych przez Marka Belkę wicepremierem i ministrem finansów został Grzegorz Kołodko (SLD).

W gabinecie Jerzego Buzka (koalicja AWS-UW) również miały miejsce roszady na stanowiskach wicepremierów. W momencie powstania rządu funkcję wicepremierów pełnili: Leszek Balcerowicz (UW) - minister finansów oraz Janusz Tomaszewski (AWS) - minister spraw wewnętrznych i administracji. Po rozpadzie koalicji Longin Komołowski został wicepremierem oraz ministrem pracy i polityki społecznej, natomiast Janusz Steinhoff, który był do tej pory ministrem gospodarki, dodatkowo został powołany na stanowisko wiceprezesa Rady Ministrów.

W minionym dwudziestoleciu obowiązywania konstytucji można dostrzec stałą prawidłowość dotyczącą częstych zmian personalnych w składzie Rady Ministrów. Do rekonstrukcji rządu dochodziło przy tym bez względu na trwałość większości rządzącej w parlamencie. Oczywiście brak tej większości sprzyjał częstszym zmianom $^{16}$, niemniej jednak wszystkie stabilne politycznie gabinety bez wyjątku także podlegały zmianom personalnym. Prawidłowość ta nie ominęła stanowisk wice-

16 Najwięcej zmian członków rządu miało miejsce w okresie pełnienia funkcji premiera przez Jerzego Buzka. Patrz: R. Mojak, Prawnoustrojowe i polityczne mechanizmy ksztattowania składu Rady Ministrów w świetle przepisów Konstytucji Rzeczpospolitej Polskiej i praktyki ustrojowej, [w:] M. Grzybowski (red.), System rządów Rzeczypospolitej Polskiej..., s. 156-161. 
prezesów Rady Ministrów. Z dotychczasowych rządów, powołanych po uchwaleniu nowej konstytucji, tylko rząd Beaty Szydło uchronił się od zmian na stanowisku wicepremiera od momentu powstania do zakończenia swego działania. We wszystkich pozostałych gabinetach zmiany te miały miejsce. $Z$ tego można wnosić, że pełnienie funkcji wicepremiera w żaden sposób nie zwiększa stabilności w sprawowaniu tego stanowiska niż pełnienie wyłącznie urzędu ministra.

Obserwacja praktyki, opisanej częściowo powyżej, pozwala na sformułowanie pewnych wniosków. Bez wątpienia najczęstszym powodem powoływania wicepremierów do składu Rady Ministrów jest koalicyjny charakter rządu. W tym przypadku najczęściej, wicepremierami zostają przywódcy partii politycznych tworzących rząd ${ }^{17}$. Stanowisko to staje się dodatkowym argumentem - „kartą przetargową" - w negocjacjach dotyczących tworzenia rządu ${ }^{18}$. Liczba wicepremierów stanowi także odzwierciedlenie koalicyjnego charakteru rządu, nawet gdy liderzy tworzących go ugrupowań nie wchodzą w skład gabinetu. Dodatkowym czynnikiem wpływającym na obsadę tych stanowisk jest podkreślenie pozycji politycznej w strukturach partii rządzącej lub partii dominującej w koalicji. Z wymienionych powyżej można, jak sądzę, wskazać kilka takich przykładów. Wydaje się, że taka geneza leżała u źródeł powołania do roli wicepremiera Przemysława Gosiewskiego, Janusza Tomaszewskiego, Ludwika Dorna czy Grzegorza Schetyny.

Jak podnosiłem wcześniej, stanowisko wicepremiera jest najczęściej łączone $\mathrm{z}$ pełnieniem urzędu ministra resortowego. $\mathrm{Z}$ reguły jest to ministerstwo o dużym znaczeniu gospodarczym lub społecznym. Wyjątkowo wicepremierzy są ministrami-członkami Rady Ministrów o szczególnym zakresie działania zadaniowego. Sytuacją niezwykłą wydaje się aktualna rola wicepremier Beaty Szydło. W zasadzie przewodniczy stale Komitetowi Społecznemu Rady Ministrów, ale to jedyna wskazówka, że w zakresie jej obowiązków leżą sprawy społeczne. Nie ma bowiem żadnego aktu prawnego czy choćby aktu prawa wewnętrznego, który by precyzował, jaki jest zakres obowiązków wicepremier Beaty Szydło. Trudno przyjąć, że w tej sytuacji wicepremier Beata Szydło koordynuje działania rządu w zakresie tzw. spraw społecznych. Komentatorzy polityczni w zasadzie zgodnie przyznają, że powierzenie jej funkcji wicepremiera było w istocie efektem braku lepszego pomysłu na polityczne zagospodarowanie byłej pani premier. Zmiana na stanowisku premiera, jaka nastąpiła w 2017 r., nie była czytelna dla dużej części opinii publicznej. Funkcja wicepremiera ma być, jak się wydaje, swoistą rekompensatą i uzasadnieniem dokonanej zmiany na stanowisku premiera.

Zestawienie ministerstw, jakie wicepremierzy zajmowali $\mathrm{w}$ dotychczasowej praktyce, pozwala na wskazanie ministerstwa, którym najczęściej kierowali. Było to Ministerstwo Finansów, a na jego czele stali następujący wicepremierzy: Le-

17 D. Górecki, Rada Ministrów, [w:] D. Górecki, K. Składowski, Prawo konstytucyjne (zagadnienia wybrane), Łódź 2010, s. 95.

18 S. Patyra, Prawnoustrojowy status..., s. 75. 
szek Balcerowicz, Marek Belka, Grzegorz Kołodko, Zyta Gilowska, Jan Vincent-Rostowski, Mateusz Morawiecki. Rzadziej rola ta przypadała ministrom spraw wewnętrznych, którymi byli: Janusz Tomaszewski, Ludwik Dorn i Grzegorz Schetyna. Można uznać, że liderzy partii rządzących w Polsce uznają, że ministerstwo finansów posiada szczególne znaczenie, zatem powierzenie kierującemu nim ministrowi dodatkowo funkcji wicepremiera podnosi jego znaczenie. Ostrożnie podchodząc do takiej tezy, można przyjąć, że ma ona pewne uzasadnienie również w tym, że część osób wymienionych powyżej pełniła funkcję wicepremiera, nie będąc przedstawicielami partii koalicyjnej i nie posiadając silnej pozycji politycznej w szeregach własnej partii.

Analizowana praktyka pokazuje, że gdy premier nie jest liderem większości parlamentarnej tworzącej rząd, to jego wpływ na decyzje personalne, w tym dotyczące wicepremierów, maleje ${ }^{19}$. Dostrzegalnym problemem w Polsce jest względna słabość pozycji premiera, która wynika z przyjętej w naszym kraju „maniery powoływania na stanowisko szefa rządu polityków niebędących rzeczywistymi liderami formacji tworzących koalicję rządzącą" ${ }^{20}$. W okresie obowiązywania Konstytucji z 1997 r. na dziewięciu premierów tylko czworo stało jednocześnie na czele partii rządzącej lub dominującej w koalicji rządzącej. Byli to: Leszek Miller, Jarosław Kaczyński, Donald Tusk i Ewa Kopacz, choć w przypadku pani premier dość powszechna była opinia, że mimo przywództwa w partii nie była jej rzeczywistym liderem, gdyż rolę tę nadal pełnił Donald Tusk. Jest to czynnik, który wyraźnie osłabia pozycję premiera w polskim systemie politycznym. Jednak nie musi to prowadzić do tworzenia w ramach rządu jakiegoś alternatywnego ośrodka władzy skupionego wokół wicepremiera. W dotychczasowej praktyce politycznej trudno wskazać na występowanie takiego zjawiska. Wydaje się, że można by taką rolę co najwyżej przypisać Matuszowi Morawieckiemu, który w rządzie Beaty Szydło pełnił funkcję wicepremiera, po czym zastąpił ją na stanowisku Prezesa Rady Ministrów. Jednak jego pozycja polityczna jako premiera, choć prawdopodobnie silniejsza niż pani premier, jest wciąż pochodną zaufania i poparcia, jakim cieszy się u rzeczywistego przywódcy PiS Jarosława Kaczyńskiego. Nie ma chyba wystarczających przesłanek, by twierdzić, że w rządzie, w którym pozycja premiera jest słabsza z powodów wskazanych powyżej, wicepremier bądź wicepremierzy uzyskują silniejszą pozycję polityczną.

Konstytucja z 2 kwietnia 1997 r. podkreśla rolę premiera jako przywódcy rządu. Jest on nie tylko jego reprezentantem, lecz także organizatorem prac rządu, kierującym jego pracami oraz całej administracji rządowej. Jego rola została wyraźnie

19 S. Patyra, Prezes Rady Ministrów pod rzq̨dami Konstytucji z 2 kwietnia 1997 r. - kanclerz czy primus inter pares?, [w:] S. Patyra, M. Sadowski, K. Urbaniak (red.), Konstytucja w państwie demokratycznym, Poznań 2017, s. 66-70.

20 S. Patyra, Parlamentaryzm zracjonalizowany a la polonaise - refleksje z perspektywy dwudziestu lat obowiązywania Konstytucji z 1997 r., „Przegląd Prawa Konstytucyjnego” 2017, nr 5, s. 44. 
wyeksponowana w postanowieniach konstytucji. Na tym tle rola wicepremierów wydaje się pozbawiona większego znaczenia. W polskiej rzeczywistości ustrojowej i politycznej to, czy są oni obecni w składzie rządu czy nie, w niewielkim stopniu wpływa na funkcjonowanie Rady Ministrów.

Santrauka

\section{Lenkijos konstitucinio reguliavimo ir politinès praktikos Ministrų Tarybos pirmininko pavaduotojas}

Ministrų Tarybos sudètis nurodyta $1997 \mathrm{~m}$. balandžio 2 d. Lenkijos Respublikos Konstitucijos 147 str. Remiantis šia tema, lenkų literatūroje šiuo klausimu dažnai nurodoma, kad Ministrų Taryba turi privalomą ir neprivalomą sudètị. Privalomąją sudètį sudaro ministras pirmininkas ir ministrai. Nuo ministro pirmininko sprendimo tuo pačiu metu priklauso, ar Ministrų Tarybos sudètyje turètų būti, be skyriaus ministrų, vadinamieji ministrai be portfelių, kurie atlieka užduotis, kurias jiems pavede ministras pirmininkas ir nustatytas jo išduoto potvarkio keliu. Tačiau neprivalomų narių sudètyje gali būti taip pat vicepirmininkas, Ministrų Tarybos vicepirmininkai ir komitetų statutuose nurodyti pirmininkai.

Ministrų Tarybos pirmininkas, be abejo, daro lemiamą ịtaką vyriausybės sukūrimui ir tam tikrai organizacinei struktūrai. Tai ypač pasakytina apie ministro pirmininko teisę atskirti Ministrų Tarybos pavaduotojų ar pirmininko pavaduotojo pareigas vyriausybejje. Ministras pirmininkas turi oficialią ir pilną laisvę, susijusią su ministro pirmininko pavaduotojų pareigomis, nusprendžia dèl jų skaičiaus, taip pat dèl to, ar jie turi derinti šią funkciją su ministro pozicija.

Žinoma, be oficialių ir teisinių veiksnių, taip pat yra ne teisinių aplinkybių, kurios gali turèti ịtakos Ministrų Tarybos formai. Tarp jų tikroji prezidento ịtaka organizacinei ir asmeninei vyriausybès sudèčiai gali būti reikšminga. Tačiau taip atsitiks, jei dvi ar daugiau aplinkybiu sutampa. Pirmasis yra parlamento daugumos nebuvimas, o antrasis - ministro pirmininko kandidato nustatymas vyriausybés formavimui ir su tuo susijusi tendencija prisiimti nuolaidas prezidentui. Jei vyriausybės formavimo metu, konstituciškai nustatyta tvarka, ministro pirmininko kandidatą palaiko parlamento dauguma, prezidento ịtaka vyriausybės formai nevyksta. Sprendimą paskirti Ministrų Tarybos pirmininko pavaduotoją gali ịkvẻpti ịvairios priežastys, tačiau visi jie turi iš esmés politinių patalpų pobūdị.

Iš literatūros matyti, kad pavadinimas ,vicepirmininkas“ reiškia, kad jis yra ar jie yra ministro pirmininko pavaduotojai, tačiau nei konstitucinès nuostatos, nei įstatymai neleidžia nustatyti priemonių ar procedūrų, susijusių su šio pavadavimo vykdymu. Mano nuomone, tokio aiškinimo, kad Ministrų Tarybos vicepirmininkas gali būti ministro pirmininko pavaduotojas, prièmimas yra sunkiai ginamas. Tokia pozicija galètų būti pateisinta situacijoje, kai Ministrų Taryboje yra tik vienas vicepirmininkas, tačiau ir šiuo 
atveju pagal ịstatymą neịmanoma kalbèti apie pakaitinị narị, nes dèl to kiekvieną kartą reikalingas ministro pirmininko leidimas.

Apskritai, ministro pirmininko pakeitimo klausimą turètų nurodyti šios institucijos būdingos ypatybès, atsiradusios dèl įstatyme numatyto sprendimo: 1) ministro pirmininko pareigas gali pakeisti Ministrų Tarybos pirmininko pavaduotojas arba vienas iš ministrų, jeigu ministro pirmininko pavaduotojas neveikia vyriausybeje, 2) vicepremjeras pavaduojant ministrą pirmininką, neveikia savo vardu, bet imasi veiksmų Ministrų Tarybos pirmininko vardu, 3) ministro pirmininko pareigų vykdymui reikia paskirti konkretų asmenị valdyti Ministrų Tarybos darbą, 4) leidimas pakeisti ministro pirmininko pareigas visada yra laikinas, 5) ministras pirmininkas gali kiekvieną kartą igalioti kitą Ministrų Tarybos narị, nebūtinai jo pavaduotoją, 6) Ministrų Tarybos pirmininko kompetencijos ribose nèra igaliojimu paskirti vienu iš Ministrų Tarybos pirmininko pavaduotojų kaip nuolatinị pavaduotoją. Remiantis galiojančiomis nuostatomis, ministro pirmininko pakeitimas nebuvo susijęs su ilgalaike praktika.

Atsižvelgiant i privalomus reglamentus, Ministro Tarybos pirmininko pavaduotojui sunku suteikti ypatingą vaidmenį, taip pat nẻra jokių sisteminių ir teisinių pozicijų, susijusių su ministrais ir kitais Ministrų Tarybos nariais. Specialusis vicepremjero vaidmuo nebuvo nurodytas Konstitucijoje, isstatyme, taip pat ir Ministrų Tarybos darbo tvarkos taisyklėse, jokioje nuostatoje nebuvo pabrèžtas ypatingas Ministrų Tarybos pirmininko pavaduotojo vaidmuo.

Atsižvelgiant $\mathfrak{i}$ tai, kad ministro pirmininko pavaduotojai dažniausiai yra Lenkijos ministrai, jų kompetencija yra susijusi su ministerijos veiklos objektu, kurio vadovu jie yra. Tradicija lygiagrečiai vykdyti ministro pirmininko pavaduotojo ir skyriaus ministro funkciją yra gerai įsitvirtinusi Lenkijoje. Nepaisant to, kad Ministrų Tarybos pirmininko pavaduotojas yra atimtas iš specialiosios prasmès, atsiradusios dèl teisinių nuostatų, jų paskyrimo praktika ị kitas vyriausybes yra plačiai paplitusi. Nuo dabartinės Konstitucijos įsigaliojimo, ministro pirmininko pavaduotojai buvo įtraukti į kiekvieną vèlesnę vyriausybę.

Politinès praktikos analizè nuo 1997 m. Konstitucijos galiojimo laikotarpio, leidžia padaryti tam tikras išvadas, leidžiančias įvertinti konstitucinị ir politinị Ministrų Tarybos pirmininko pavaduotojo statusą. Praeities praktika patvirtina teiginį, kad ministro pirmininko pavaduotojai taip pat yra kažkokio skyriaus ministrai. Daugiau nei dvidešimt vicepremjerų, kurie iki šiol buvo vẻlesnių vyriausybių dalis, tik trys ministrai nebuvo atsakingi už administracijos padalinį. Ministro pirmininko pavaduotojų skaičius vèlesnèje Ministrų Taryboje niekada nebuvo didesnis nei trys, tačiau tuo pat metu ne mažiau kaip du.

Per pastaruosius du Konstitucijos galiojimo dešimtmečius galima pastebèti nuoseklumą dèl dažnų personalo pokyčių Ministrų Tarybos sudètyje. Vyriausybẻ buvo rekonstruota, neatsižvelgiant ị valdančiosios daugumos parlamento ilgaamžiškumą. Toks dėsningumas neišvengė Ministrų Tarybos pirmininko pavaduotojų pareigybių. Iš ankstesnių vyriausybių, paskirtų po to, kai buvo priimta nauja konstitucija, tiktai Beatos Szydło vyriausybė išgelbejjo save nuo pokyčių, susijusių su ministro pirmininko pavaduotojo pareigomis, nuo jo sukūrimo iki jo veiklos pabaigos. Visuose kituose kabinetuose šie pokyčiai vyko. Iš to galima teigti, kad vicepremjero pareigų vykdymas, jokiu būdu nepadidina šios pozicijos stabilumo einant šias pareigas nei atliekant vien tik ministro tarnybą.

Praktikos stebejjimas leidžia suformuluoti tam tikrus dèsningumus. Be abejo, dažniausia Ministrų Tarybos pirmininko pavaduotojų paskyrimo priežastis yra vyriausybès koalicinis 
pobūdis. Šiuo atveju dažniausiai vicepremjerai yra vyriausybès formuojančiu politinių partijų vadovai. Ši pozicija tampa papildomu argumentu, ,derybų kortele“ derybose dèl vyriausybès sukūrimo. Ministro pirmininko pavaduotojų skaičius taip pat atspindi koalicinį vyriausybės charakterị, net kai jos sudedamųjų grupių vadovai nėra kabineto dalis. Papildomas veiksnys, darantis įtaką daugybei šiu pozicijų, yra politinės pozicijos valdančiosios partijos struktūrose arba dominuojančios partijos koalicijoje pabrěžimas.

Ministerijų sąrašas, kurị užèmé ankstesnèje praktikoje vicepremjerai, leidžia nurodyti ministeriją, kurią dažniausiai valdè. Tai buvo Finansų ministerija, o jo vadovai buvo šie ministro pavaduotojai: Leszek Balcerowicz, Marek Belka, Grzegorz Kołodko, Zyta Gilowska, Jan Vincent-Rostowski, Mateusz Morawiecki. Galima daryti prielaidą, kad Lenkijos partijų lyderiai pripažista, kad ši ministerija turi ypatingą reikšmę ir jai vadovaujančiam ministrui pavedama vicepremjero pareiga, taip pat padidina jo reikšmę. Atidžiai artejjant prie tokios tezès, galima manyti, kad ji turi tam tikrą pagrindimą ir kad kai kurie finansų ministrai veikè kaip ministro pirmininko pavaduotojai, neturèdami stiprios politinès padèties savo partijos ratuose.

Svarbi Lenkijos problema yra santykinis premjero pareigų silpnumas, kurị lemia Lenkijoje priimta praktika, paskirti vyriausybès vadovavimui politikus, kurie nèra tikri formacijos, sudarančios valdančiąją koaliciją, lyderiai. $1997 \mathrm{~m}$. Konstitucijos galiojimo laikotarpiu iš devynių premjerų, tik keturi tuo pačiu metu vadovavo valdančiai arba dominuojančiai valdančiosios koalicijos partijai. Tai yra veiksnys, kuris akivaizdžiai silpnina premjero postą Lenkijos politinèje sistemoje.

$1997 \mathrm{~m}$. balandžio $2 \mathrm{~d}$. Konstitucija pabrěžia premjero vaidmenį kaip vyriausybès lyderi. Jis yra ne tik jos atstovas, bet ir vyriausybės darbo organizatorius, vadovaujantis jos darbui ir visai vyriausybei administracijai. Jo vaidmuo pagal konstitucines nuostatas tapo

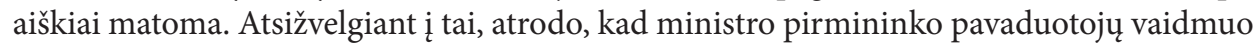
yra mažiau svarbus. Lenkijos sistemoje ir politinèje realybeje, ar jie yra vyriausybès dalis, ar ne, nedidele įtaką funkcionavimui daro Ministrų Tarybos veikimas.

\section{Literatura}

Bożek M., Zapewnienie ciagłości w kierowaniu pracami Rady Ministrów pod rządami Konstytucji RP, „Przegląd Sejmowy” 2010, nr 6.

Brodziński W., Rada Ministrów, [w:] D. Górecki (red.), Polskie prawo konstytucyjne, wyd. V, Warszawa 2015.

Górecki D., Rada Ministrów, [w:] D. Górecki, K. Składowski, Prawo konstytucyjne (zagadnienia wybrane), Łódź 2010.

Grzybowski M., Konstytucyjne $i$ ustawowe uwarunkowania struktury rządu a praktyka ustrojowa, [w:] M. Grzybowski (red.), System rządów Rzeczypospolitej Polskiej. Założenia konstytucyjne a praktyka ustrojowa, Warszawa 2006. 
Grzybowski M., Pozycja ustrojowa Wiceprezesa Rady Ministrów, [w:] P. Tuleja, M. Florczak-Wątor, S. Kubasa (red.), Prawa człowieka, społeczeństwo obywatelskie, państwo demokratyczne. Ksiega jubileuszowa dedykowana Profesorowi Pawłowi Sarneckiemu, Warszawa 2010.

Mojak R., Prawnoustrojowe i polityczne mechanizmy kształtowania składu Rady Ministrów w świetle przepisów Konstytucji Rzeczpospolitej Polskiej i praktyki ustrojowej, [w:] M. Grzybowski (red.), System rząów Rzeczypospolitej Polskiej. Założenia konstytucyjne a praktyka ustrojowa, Warszawa 2006.

Mojak R., Władza wykonawcza - Rada Ministrów i administracja rządowa, [w:] E. Gdulewicz (red.), Konstytucyjny system organów państwowych, Lublin 2009.

Patyra S., Parlamentaryzm zracjonalizowany à la polonaise - refleksje z perspektywy dwudziestu lat obowiązywania Konstytucji z 1997 r., „Przegląd Prawa Konstytucyjnego” 2017, nr 5.

Patyra S., Prawnoustrojowy status Prezesa Rady Ministrów w świetle Konstytucji z 2 kwietnia 1997 r., Warszawa 2002.

Patyra S., Prezes Rady Ministrów pod rządami Konstytucji z 2 kwietnia 1997 r. - kanclerz czy primus inter pares?, [w:] S. Patyra, M. Sadowski, K. Urbaniak (red.), Konstytucja w państwie demokratycznym, Poznań 2017.

Sarnecki P., Uwaga do art. 147, [w:] L. Garlicki (red.) Konstytucja Rzeczypospolitej Polskiej. Komentarz, t. II, Warszawa 2001.

Składowski K., System rządów w Republice Chorwacji, Łódź 2013.

Skrzydło W., Konstytucja Rzeczypospolitej Polskiej. Komentarz, Kraków 2002.

\section{Akty prawne}

Konstytucja Rzeczypospolitej Polskiej z dnia 2 kwietnia 1997 r., Dz.U. z 1997 r., nr 78, poz. 483.

Ustawa z dnia 8 sierpnia 1996 r. o Radzie Ministrów, Dz.U. z 1996 r., nr 106, poz. 492.

Ustawa z dnia 4 września 1997 r. o działach administracji rządowej, Dz.U. z 1997 r., nr 141, poz. 943.

Uchwała nr 190 Rady Ministrów z 29 października 2013 r. - Regulamin pracy Rady Ministrów, tekst jedn. M.P. z 2016 r., poz. 1006. 